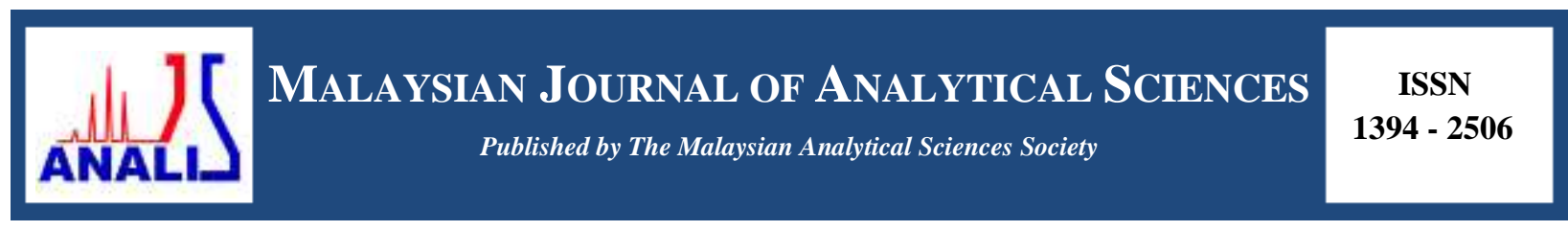

\title{
OPTICAL CHEMICAL SENSOR OF Cd(II) IN WATER BASED ON 1-(2-PYRIDYLAZO)-2-NAPHTOL IMMOBILIZED ON POLY(METHYL METHACRYLATE) AND 2-NITROPHENYL OCTYL ETHER MATRIX
}

\author{
(Sensor Kimia Optik untuk Penentuan Cd(II) dalam Air Berasaskan \\ 1-(2-Piridilazo)-2-Naftol yang Dipegun dalam Matriks Poli(metil metaakrilat) dan \\ 2-Nitrofenil Oktil Eter) \\ Moersilah $^{1,2}$, Dwi Siswanta ${ }^{1}$, Roto Roto $^{1}$, Mudasir Mudasir $^{1 *}$ \\ ${ }^{l}$ Department of Chemistry, Faculty of Mathematics and Natural Sciences, \\ Universitas Gadjah Mada, Sekip Utara, Yogyakarta, 55281 Indonesia \\ ${ }^{2}$ Department of Chemistry, Faculty of Mathematics and Science, \\ State University of Jakarta, Jl. Pemuda No. 10 Jakarta Timur, Jakarta, Indonesia \\ *Corresponding author: mudasir@ugm.ac.id
}

Received: 18 January 2017; Accepted: 22 May 2017

\begin{abstract}
An optical chemical sensor for determination of $\mathrm{Cd}(\mathrm{II})$ in aqueous solution has been developed by immobilizing 1-(2pyridylazo)-2-naphtol (PAN) in poly(methyl methacrylate) (PMMA) as a matrix and 2-nitrophenyl octyl ether (NPOE) as a plasticizer. The adsorption of $\mathrm{Cd}(\mathrm{II})$ causes the color of the membrane to change from yellow to red-orange with the maximum absorbance $\left(\lambda_{\max }\right)$ at $556 \mathrm{~nm}$. The sensor membrane gives the best response towards $\mathrm{Cd}(\mathrm{II})$ ion at $\mathrm{pH} 8.5$, after 120 minutes of contact time, at $2 \mathrm{ppm} \mathrm{Cd(II),} \mathrm{and} 2 \mathrm{~mL}$ solution. A linear Cd(II) calibration curve can be developed in the concentration range of $0.8-1.8 \mathrm{ppm}$ with $\mathrm{R}^{2}=0.960$. The limit of the detection and limit of quantification are $0.041 \mathrm{ppm}$ and $0.126 \mathrm{ppm}$, respectively. The molar absorptivity is found to be $2.3 \times 10^{5} \mathrm{~L} \mathrm{~mol}^{-1} \mathrm{~cm}^{-1}$. The proposed sensor membrane has been applied to the determination of $\mathrm{Cd}(\mathrm{II})$ in the river water with internal standard addition method. The observed percent recovery is in the range of $100.24-107.52 \%$.
\end{abstract}

Keywords: optical chemical sensor, 1-(2-pyridylazo)-2-naphtol, Cd(II) analysis, poly(methyl methacrylate)

\begin{abstract}
Abstrak
Reagen 1-(2-piridilazo)2-naftol (PAN) yang dipegun dalam poli(metil metaakrilat) (PMMA) dengan 2-nitrofenil oktil eter (NPOE) sebagai pemplastik untuk sensor kimia optik bagi penentuan ion Cd(II) dalam larutan akues telah dibangunkan. Jerapan ion $\mathrm{Cd}$ (II) telah menyebabkan penukaran warna dari kuning menjadi merah-oren dengan serapan maksimum pada $\left(\lambda_{\max }\right)$ iaitu $556 \mathrm{~nm}$. Membran sensor memberikan tindak balas maksimum apabila dicelupkan dalam larutan Cd(II) pada pH 8.5, selepas 120 minit masa sentuhan pada kepekatan $2 \mathrm{ppm} \mathrm{Cd}(\mathrm{II})$ dan $2 \mathrm{ml}$ isipadu larutan. Berdasarkan kajian yang dijalankan, julat linear lengkung kalibrasi kepekatan ion Cd(II) ialah $0.8-1.8 \mathrm{ppm}$ dan nilai $\mathrm{R}^{2}=0.960$. Had pengesanan dan pengkuantitian yang diperolehi masing - masing ialah $0.041 \mathrm{ppm}$ dan $0.126 \mathrm{ppm}$. Daya penyerapan molar dikira pada $2.3 \times 10^{5} \mathrm{~L} \mathrm{~mol}^{-1} \mathrm{~cm}^{-1}$. Membran sensor ini telah dikaji untuk menentukan kepekatan Cd(II) dalam air sungai yang dipaku kaesah larutan piawai dalam. Ia telah menghasilkan pemulihan semula pada nilai $100.24-107.52 \%$.
\end{abstract}

Kata kunci: Sensor kimia optik, 1-(2-piridilazo)2-naftol, analisis Cd(II), poli(metil metaakrilat) 


\section{Moersilah et al: OPTICAL CHEMICAL SENSOR OF Cd(II) IN WATER BASED ON 1-(2-PYRIDYLAZO)-2- NAPHTOL IMMOBILIZED ON POLY(METHYL METHACRYLATE) AND 2- NITROPHENYL OCTYL ETHER MATRIX}

\section{Introduction}

Cadmium (Cd) is one of the heavy metals that can pollute the environment even in a trace amount. $\mathrm{Cd}(\mathrm{II})$ ion in water also has a significant influence towards water quality and public health. The maximum permitted contents of $\mathrm{Cd}$ in waste and drinking water are 0.1 and $0.05 \mathrm{ppm}$, respectively [1]. Cd is harmful to health since it is both toxic and carcinogenic [2-4]. Therefore, a simple, rapid, sensitive and low-cost method of analysis is required for monitoring $\mathrm{Cd}(\mathrm{II})$ content in the environment.

The conventional standard methods for metal determination are atomic absorption spectrophotometer (AAS) and Flame-AAS [5, 6]. These methods are sensitive and selective. However, it is relatively expensive and requires a skilled person to do the job. The chemo-optic sensor is an alternative method for metal analysis. It is part of the green analytical methods since it can significantly reduce energy consumption, organic solvents, and gas emission. Therefore, it is much more environmentally friendly [7-10].

Several studies on optical chemical sensors have been carried out based on the immobilization of colored complexing reagents in an appropriate polymer membrane. For example, an optical chemical sensor for Cd(II) determination has been developed using various techniques such as in cellulose acetate membrane by immobilization of 1-(2-piridilazo)-2-naftol (PAN) [11], 2-amino-cyclopentene-1-dithiocarboxylic acid (ACDA) [12], and dithizone [13]. Immobilization of PAN in the poly-methyl methacrylate membrane has been applied in the determination of $\mathrm{Cd}(\mathrm{II}), \mathrm{Ni}(\mathrm{II}), \mathrm{Cu}(\mathrm{II}), \mathrm{Zn}(\mathrm{II}), \mathrm{Pb}$ (II), and $\mathrm{Co}$ (II) [14, 15]. Also, polyvinyl chloride (PVC) based chemo-optic sensor as a matrix for pyridylazo resorcinol (PAR) using tributhyl phosphate (TBP) as a plasticizer for Th(III) determination has also been described by Ensafi and Fouldagar [16].

1-(2-piridilazo)-2-naftol (PAN) possesses azo-nitrogen and $\mathrm{OH}$ groups (Figure 1). It reacts with transition metals to form a colorful complex. PAN is an unselective coloring reagent. However, its selectivity over other metal ions can be enhanced by adjusting the $\mathrm{pH}$ of the solution in accordance with the targeted metal ions [17]. Cd(II) in alkaline media forms a stable color complex with PAN, which can be extracted into organic solvents $[17,18]$.

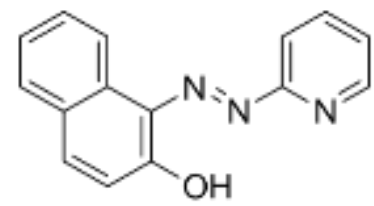

Figure 1. Molecular structure of PAN

In this study, we have developed a chemo-optic Cd(II) sensing method, which is simple, safe, inexpensive, environmentally friendly and oriented to green analytical chemistry. The sensing membrane is developed based on immobilization of PAN in poly-methyl methacrylate (PMMA) membrane using 2-nitrophenyl octyl ether (NPOE) as plasticizer.

\section{Chemicals and instruments}

\section{Materials and Methods}

Cadmium(II) nitrate $\left[\mathrm{Cd}\left(\mathrm{NO}_{3}\right)_{2}\right]$, sodium hydroxide $(\mathrm{NaOH})$, hydrochloric acid $(\mathrm{HCl})$, copper(II) chloride $\left(\mathrm{CuCl}_{2}\right)$, zinc(II) nitrate $\left[\mathrm{Zn}\left(\mathrm{NO}_{3}\right)_{2}\right]$, nickel(II) nitrate $\left[\mathrm{Ni}\left(\mathrm{NO}_{3}\right)_{2}\right]$, iron(III) chloride $\left(\mathrm{FeCl}_{3}\right)$ and tetrahydrofuran (THF) were obtained from Merck. 1-(2-pyridylazo)-2-naphtol (PAN) and 2-nitrophenyl octyl ether (NPOE) were analytical grades and purchased from Sigma-Aldrich. Poly-methyl methacrylate (PMMA) was obtained by synthesis with an average molecular weight of about 220,000. The double distilled water was used as a solvent throughout the UVVisible spectrophotometric measurements. The $\mathrm{pH}$ of the solution was adjusted by drop wise addition of either $0.10 \mathrm{M} \mathrm{NaOH}$ or $0.10 \mathrm{M} \mathrm{HCl}$ and monitored by using Thermo Scientific (ORION 4 STAR, pH-ISE Portable) pHmeter. A Shimadzu UV-Visible spectrophotometer UV-2450 model and A Shimadzu FTIR spectrophotometer, Prestige-21 type model, were used to measure the UV-Visible and FTIR spectra. 


\section{Preparation of sensor membrane}

The sensor membrane was prepared by dissolving $0.4000 \mathrm{~g}$ PMMA, $0.0100 \mathrm{~g}$ PAN, and $120 \mu \mathrm{L}$ NPOE in $10 \mathrm{~mL}$ THF, and stirring the mixture at a constant speed for 5 hours at room temperature. Subsequently, the reaction mixture was poured into a casting glass $(5 \mathrm{~cm} \times 12 \mathrm{~cm})$ and kept at room temperature for $10-12$ hours, until all the solvent evaporated. The membranes were released from the cast, washed with distilled water, dried at room temperature, and cut into rectangle shape $(0.8 \mathrm{~cm} \times 2 \mathrm{~cm})$. The membrane thickness was c.a. $0.05 \mathrm{~mm}$.

\section{Characterization of sensor membrane}

The FTIR spectra of PAN, NPOE, PMMA and PMMA-PAN membrane were recorded using A Shimadzu FTIR spectrophotometer.

\section{Determination of optimum pH}

The optimum $\mathrm{pH}$ was determined by measuring the absorbance of membranes that were previously soaked in $2 \mathrm{~mL}$ solution containing $2 \mathrm{ppm}$ of the $\mathrm{Cd}(\mathrm{II})$ ion in the $\mathrm{pH}$ range of $7.0-9.0$ for a defined time. The optimum $\mathrm{pH}$ was indicated by maximum absorbance at $556 \mathrm{~nm}$.

\section{Range of linearity}

The linear range of absorbance of Cd(II)-PAN complex was studied at Cd(II) concentration of $0.2-2.0 \mathrm{ppm}$.

\section{Interfering ions}

The interfering ions including $\mathrm{Cu}(\mathrm{II}), \mathrm{Zn}(\mathrm{II}), \mathrm{Ni}(\mathrm{II})$, and $\mathrm{Fe}(\mathrm{III})$ were studied by measuring the absorbance of the solution in the presence of the interfering cations and $\mathrm{Cd}(\mathrm{II})$ in the concentration ratio of $1: 1$ at $556 \mathrm{~nm}$ and $\mathrm{pH} 8.5$.

\section{Application in water sample}

The membrane was applied for analysis of $\mathrm{Cd}(\mathrm{II})$ in the stream water of "Kali Code" flowing across the City of Yogyakarta, Indonesia. A measured $100 \mathrm{~mL}$ of river water sample was acidified using $\mathrm{HNO}_{3} 1.0 \mathrm{M}$ until pH about 3 , filtered off and stored in a propylene bottle at room temperature. For Cd(II) determination, the $\mathrm{pH}$ of the sample solution was adjusted to $\mathrm{pH} 8.5$ by adding $\mathrm{NaOH} 0.1 \mathrm{M}$ solution. Note: "Kali Code" is the name of the river that flows across City of Yogyakarta, Indonesia, starting from Merapi Mountain in the north to the Indian Ocean in the south.

\section{Results and Discussion}

\section{Supporting matrix stability and sensor membrane response toward Cd(II)}

PMMA was chosen as a supporting matrix for PAN due to its hydrophobicity, transparency, resistance to acid, base and salt solutions [19], and low absorbance in the UV-Vis range [20]. These will keep the sensor membrane stable during analysis of $\mathrm{Cd}(\mathrm{II})$ in water and allow quantitative analysis by UV-Vis spectrophotometry.

As a ligand, PAN can form a colorful complex ion with a number of cations, that are Cd(II) [11, 14], Co(II) [15], $\mathrm{Cr}(\mathrm{III})$ [21]. The complex ions of PAN with those cations are formed through the coordination bond between $-\mathrm{OH}$ and azo-nitrogen groups of the phenolic ring with the cations. Based on known stoichiometry, the $\mathrm{Cd}(\mathrm{II}) / \mathrm{PAN}$ molar ratio is 1:2 [17, 22]. The reaction of metal complex formation is displayed in Figure 2.

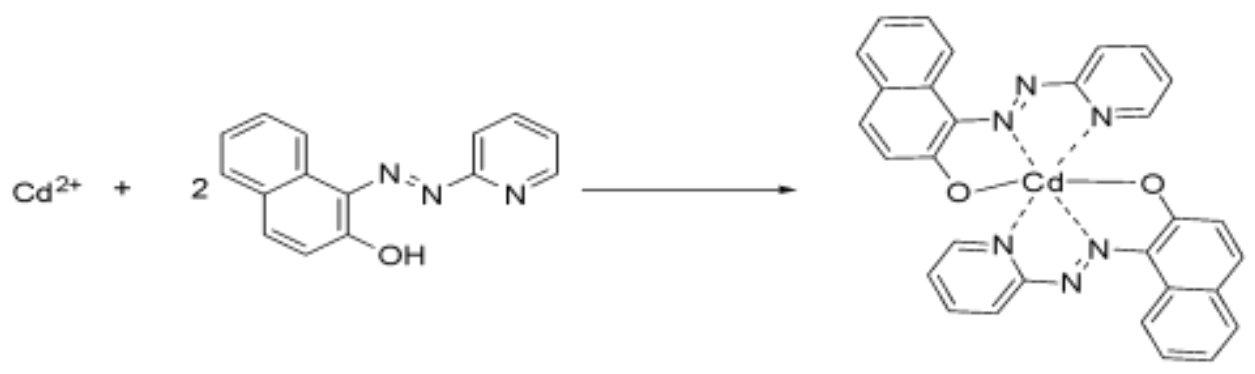

Figure 2. Reaction scheme for the complex formation of Cd(II) - PAN 


\section{Moersilah et al: OPTICAL CHEMICAL SENSOR OF Cd(II) IN WATER BASED ON 1-(2-PYRIDYLAZO)-2- NAPHTOL IMMOBILIZED ON POLY(METHYL METHACRYLATE) AND 2- NITROPHENYL OCTYL ETHER MATRIX}

\section{Membrane characterization}

The FTIR spectra of PAN immobilized in the membrane matrix are shown in Figure 3. It is clearly shown in the Fig. 3d that PAN has been successfully incorporated into the membrane. The peak at $3441 \mathrm{~cm}^{-1}$ indicates a stretching vibration of $-\mathrm{OH}$ group of naphtol, whereas the peak at $2338 \mathrm{~cm}^{-1}$ is due to the $\mathrm{N}=\mathrm{N}$ group. The medium peak at $1605 \mathrm{~cm}^{-1}$ is attributed to the $\mathrm{N}=\mathrm{O}$ bond. Further, the peak at $1250 \mathrm{~cm}^{-1}$ suggests the presence of $\mathrm{C}_{\text {aryl }} \mathrm{O}$ $\mathrm{C}_{\text {alkyl }}$ group. Both peaks reveal the existence of NPOE as a plasticizer in the membrane.

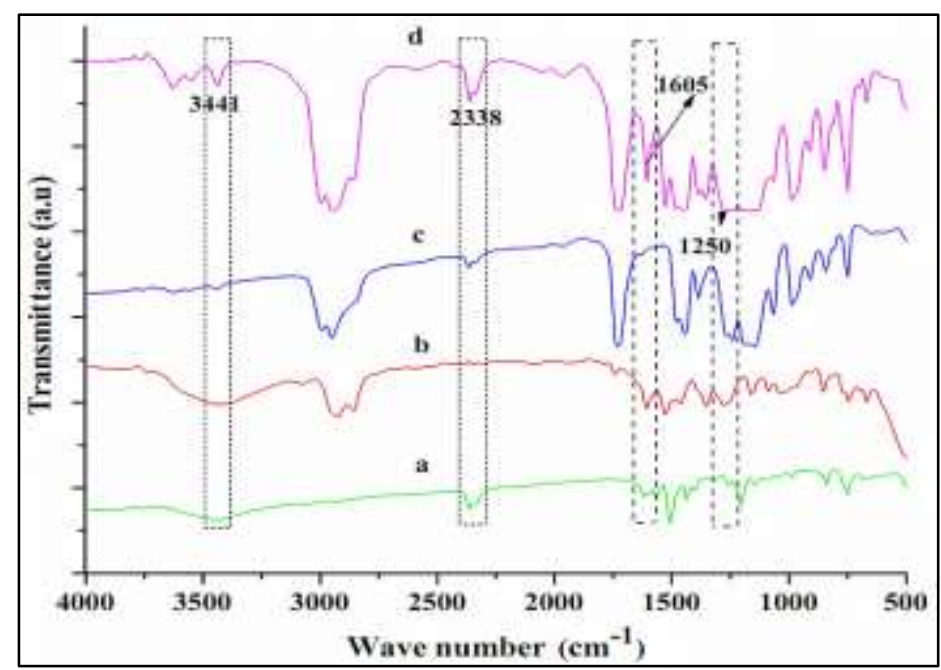

Figure 3. Infrared spectra of the membrane components (a) PAN, (b) NPOE, (c) PMMA and (d) PMMA-PAN membrane

\section{The effect of $\mathrm{pH}$ on sensing performance}

The $\mathrm{pH}$ of the test solutions plays an important role in obtaining a better membrane performance. The analyte solution has been subjected to $\mathrm{pH}$ variation, from 7.0 to 9.0. Figure 4 suggests that the solution $\mathrm{pH}$ of 8.5 gives the best response. It has been previously reported in many works that the best $\mathrm{pH}$ for $\mathrm{Cd}(\mathrm{II})-\mathrm{PAN}$ complex formation is at pH $8.7-10$ with $\lambda_{\max }$ of $540-570 \mathrm{~nm}$ [17,22] or $\lambda_{\max }$ of $550-560 \mathrm{~nm}$ [18]. In case of optimum pH of Cd(II)PAN complex formation in the membranes, it has also been reported that the optimum $\mathrm{pH}$ in the PVC membrane using NPOE as plasticizer is at $\mathrm{pH} 8.0$ and $\lambda_{\max }$ of $558 \mathrm{~nm}$ [23]. Similarly, the optimum $\mathrm{pH}$ in the cellulose triacetate membrane using TEHP as a plasticizer is at $\mathrm{pH} 7.5$ with $\lambda_{\max }$ of $553 \mathrm{~nm}$ [11]. Therefore, our result of optimum $\mathrm{pH}$ at 8.5 , is in good agreement with previously reported works. For this study, the absorbance of the membrane was recorded after $105-125 \mathrm{~min}$ of reaction.

Furthermore, at optimum $\mathrm{pH}$, the amount of $\mathrm{OH}^{-}$ion in the solution is larger and the donor atom in the ligand tends to release $\mathrm{H}^{+}$ion (deprotonated) and thus becomes partially negative-charged species ( $\mathrm{L}^{-}$). This condition enhances the reaction between $\mathrm{Cd}^{2+}$ or $[\mathrm{Cd}(\mathrm{OH})]^{+}$in the solution and PAN ligand in the matrix to form $\mathrm{CdL}_{2}$. On the other hand, at lower $\mathrm{pH}$, large amount of $\mathrm{H}^{+}$in the solution causes the formation of free metal ion $\left(\mathrm{M}^{\mathrm{n}+}\right)$ and the hydroxyl group in the ligand remains protonated. This situation causes the interaction between metal ion and ligand much more difficult to occur due to charge repulsion between positive metal ion and positively protonated ligand. At higher $\mathrm{pH}(>9.0)$, the absorbance is getting smaller possibly due to leaching process of PAN ligand from the membrane matrix as indicated by the red-color change of the solution. For all of the tested $\mathrm{pH}$, the absorbance has been observed to reach its maximum value after 180 min of reaction. 


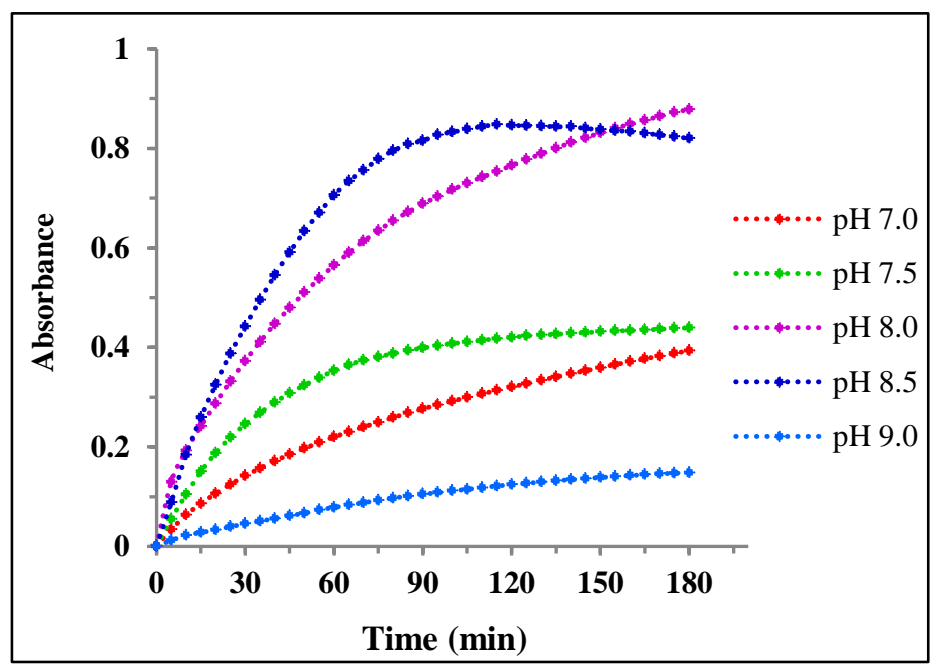

Figure 4. The response of sensor membrane at different $\mathrm{pH}$ with cadmium concentration of $2 \mathrm{ppm}(\mathrm{n}=3)$

\section{Range of linearity}

The linear range of the sensor membrane for $\mathrm{Cd}(\mathrm{II})$ analysis was examined. The $\mathrm{Cd}(\mathrm{II})$ concentration was set at 0.2 $-2.0 \mathrm{ppm}$ and the obtained data are shown in Figure 5. The absorbance linearly increases along with the increasing in the $\mathrm{Cd}(\mathrm{II})$ concentration, from $0.08-1.8 \mathrm{ppm}$. From the curve, it has been obtained that the detection limit of $\mathrm{Cd}$ (II) is $0.041 \mathrm{ppm}$ with $\mathrm{R}^{2}=0.960$.

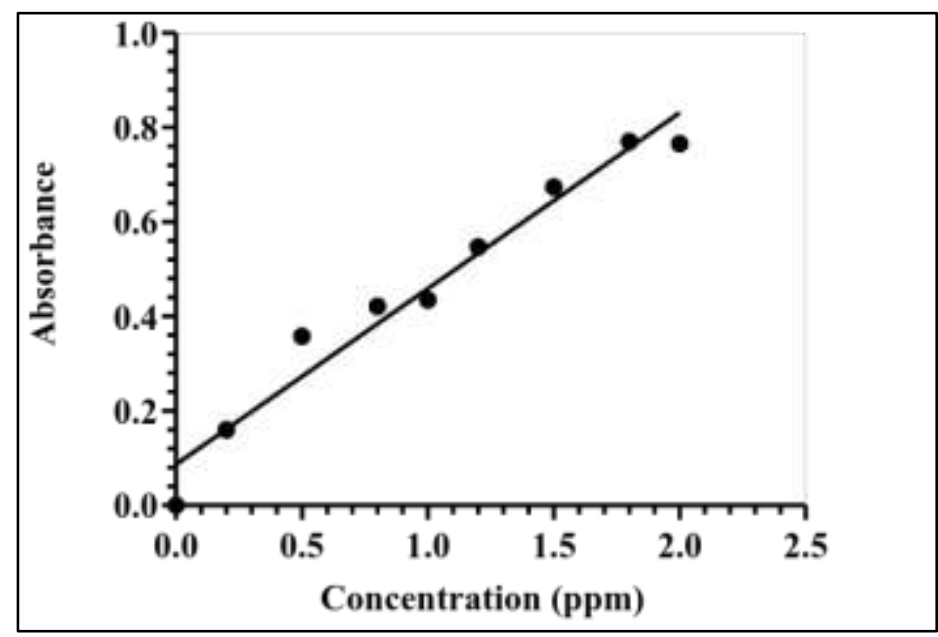

Figure 5. Calibration curve of $\mathrm{Cd}(\mathrm{II})$ sensor membrane. The absorbance was recorded at $\lambda 556 \mathrm{~nm}$

\section{Response of sensor membrane}

The UV-Vis spectra of sensing membrane before and after contact with Cd(II) solution are displayed in Figure 6 . Before contact with $\mathrm{Cd}(\mathrm{II})$ solution, the sensor membrane has maximum absorbance $\left(\lambda_{\max }\right)$ at $466 \mathrm{~nm}$, and after contact with $\mathrm{Cd}(\mathrm{II})$ solution at $\mathrm{pH} 8.5$, it shifts to $556 \mathrm{~nm}$. The formation of complex Cd(II)-PAN in the sensor membrane exhibits significant bathochromic shift from 466 to $556 \mathrm{~nm}$. It has been reported that the $\lambda_{\max }$ of PAN and $\mathrm{Cd}$ (II)-PAN complex in chloroform is $470 \mathrm{~nm}$ and between $540-570 \mathrm{~nm}$, respectively [22]. The slight difference in our results may be due to the sensitivity of PAN in different environments that lead to shift in $\lambda_{\max }$ 


\section{Moersilah et al: OPTICAL CHEMICAL SENSOR OF Cd(II) IN WATER BASED ON 1-(2-PYRIDYLAZO)-2- NAPHTOL IMMOBILIZED ON POLY(METHYL METHACRYLATE) AND 2- NITROPHENYL OCTYL ETHER MATRIX}

when it packs in the solid membrane matrices [24]. It is noteworthy to note that the cation permeability in the polymer matrix is lower than that in the solution. This may also cause the shift of $\lambda_{\max }$.

For comparison, it has been reported that the $\lambda_{\max }$ of PAN and Cd(II)-PAN complex in the CTA membrane is observed at 466 and $553 \mathrm{~nm}$, respectively. The membrane was prepared by solvent mixing of $10 \mathrm{~mL}$ dichloromethane and $10 \mathrm{~mL}$ chloroform, and dried for 48 hours. By using this reported membrane, it has been found that the linear range of $\mathrm{Cd}$ (II) calibration curve was in the range of $0.01-5.0 \mathrm{ppm}$ and the equilibrium time for complex formation was achieved after 150 minutes of reaction at $\mathrm{pH} 7.5$ [11]. It is, therefore, obvious that our results is superior than those previously reported, especially in term of response time (120 minutes), required sample size ( $2 \mathrm{~mL}$ only), less usage solvent and shorter evaporation time, meaning that the preparation of the sensing membrane in our study produces less waste, reduces gas emission and needs shorter analysis time.

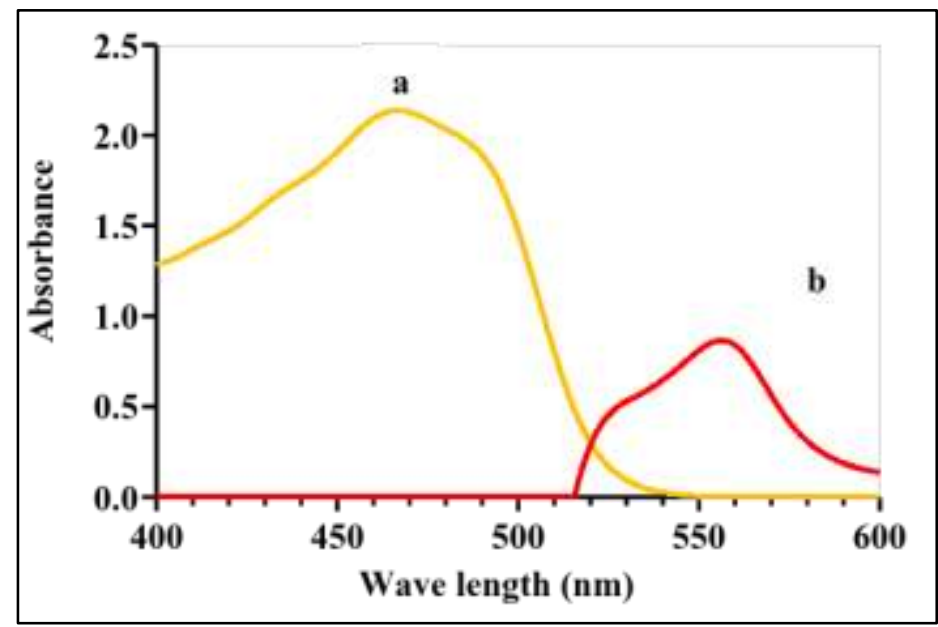

Figure 6. Absorption spectra of sensor membrane before (a) and after (b) contact with $2 \mathrm{ppm} \mathrm{Cd}(\mathrm{II})$ solution at $\mathrm{pH}$ 8.5

After contact with Cd(II) solution, the membrane color changes from yellow to red-orange as shown in Figure 7. The color intensity of the membrane increases along with the increase of the concentration of $\mathrm{Cd}(\mathrm{II})$ in the solution.

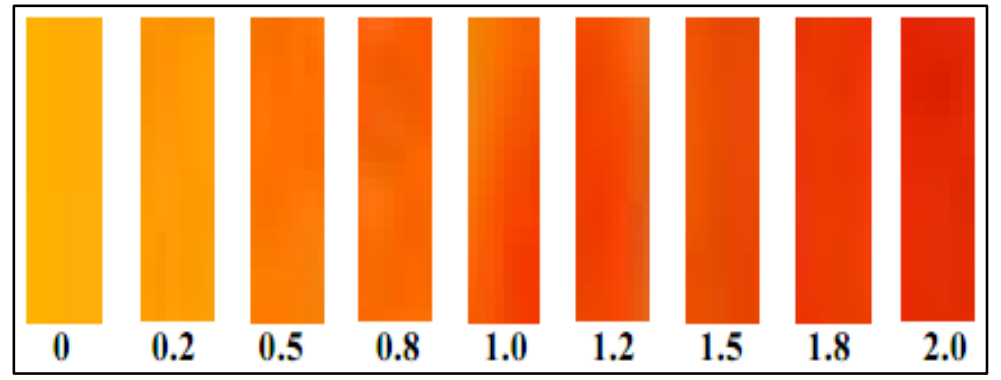

Figure 7. Progress of sensor membrane color change along with increase in $\mathrm{Cd}(\mathrm{II})$ concentration

\section{Effect of the other cations}

The response of the membrane towards $\mathrm{Cd}(\mathrm{II})$ ion in the presence of other cations such as $\mathrm{Cu}$ (II), $\mathrm{Zn}$ (II), $\mathrm{Ni}$ (II) and $\mathrm{Fe}(\mathrm{III})$ was tested. The experiment was conducted at the optimized conditions of $\mathrm{Cd}(\mathrm{II})$ analysis. The membrane was immersed separately in each solution containing both the interfering cation and $\mathrm{Cd}(\mathrm{II})$ ion at $\mathrm{pH} 8.5$ for 120 
min. The mole ratio of $\mathrm{Cd}(\mathrm{II}) /$ interfering cation was set at 1:1, and the absorbance was measured at $556 \mathrm{~nm}$. The results of the study are presented in Table 1.

Table 1. Effect of other cations on the sensing response

\begin{tabular}{llc}
\hline No. & Cation & \%Error* \\
\hline 1. & $\mathrm{Cu}(\mathrm{II})$ & -18.92 \\
2. & $\mathrm{Zn}(\mathrm{II})$ & 9.56 \\
3. & $\mathrm{Ni}(\mathrm{II})$ & 2.05 \\
4. & $\mathrm{Fe}(\mathrm{III})$ & 7.06 \\
5. & $\mathrm{Cu}, \mathrm{Zn}, \mathrm{Ni}, \mathrm{Fe}(\mathrm{III})$ & 33.35 \\
\hline
\end{tabular}

*\% Error was calculated using equation, $\left\{\left(\mathrm{A}_{\mathrm{Cd}(\mathrm{II}) \text {-cation }}-\mathrm{A}_{\mathrm{Cd}(\mathrm{II})}\right) / \mathrm{A}_{\mathrm{Cd}(\mathrm{II})}\right\} \times 100 \%[25]$

$\mathrm{A}_{\mathrm{Cd}(\mathrm{II})-\text { cation }}$ is the absorbance of sensor membrane in $\mathrm{Cd}(\mathrm{II})$ solution containing interference cation, and $\mathrm{A}_{\mathrm{Cd}(\mathrm{II})}$ is the absorbance of sensor membrane in $\mathrm{Cd}(\mathrm{II})$ solution without interference cation.

From Table 1, it is easily understood that the co-existence of $\mathrm{Cu}(\mathrm{II})$ in the solution causes the negative error (decrease in absorbance) of about $19 \%$ against the absorbance of single solution containing Cd(II)-PAN complex. It has been reported that $\mathrm{Cu}(\mathrm{II})$ ion can form stable complex, $\mathrm{Cu}$ (II)-PAN with PAN but the optimum condition of the complex formation is at $\mathrm{pH} 3.2$ with $\lambda_{\max }$ of $550 \mathrm{~nm}$ [17], while the optimum complex formation for $\mathrm{Cd}(\mathrm{II})-\mathrm{PAN}$ is at $\mathrm{pH}$ 8.5. Because of the large difference in the formation $\mathrm{pH}$ of $\mathrm{Cu}(\mathrm{II})-\mathrm{PAN}$ and $\mathrm{Cd}(\mathrm{II})-\mathrm{PAN}$ complexes, it is expected that the competition between the two cations to interact with PAN not occur in the solution. The 19\% decrease in absorbance of $\mathrm{Cu}(\mathrm{II})$-PAN is most likely due to the decrease in the diffusion of the $\mathrm{Cd}(\mathrm{II})$ in the membrane sensor caused by the presence of $\mathrm{Cu}(\mathrm{II})$ ion.

Unlike $\mathrm{Cu}(\mathrm{II})$, the co-presence of $\mathrm{Zn}(\mathrm{II}), \mathrm{Ni}(\mathrm{II})$ and $\mathrm{Fe}(\mathrm{III})$ in the solution shows positive errors (increase in absorbance). From the literature, it is known that the best $\mathrm{pH}$ for the formation of $\mathrm{Zn}(\mathrm{II})-\mathrm{PAN}$ and $\mathrm{Ni}(\mathrm{II})-\mathrm{PAN}$ complexes is at $\mathrm{pH} 10$ [22] and $\mathrm{pH} 4-10$ [17], respectively. The $\mathrm{Zn}(\mathrm{II})-\mathrm{PAN}$ in chloroform have $\lambda_{\max }$ at $550-570$ $\mathrm{nm}$, which is quite close to the $\lambda_{\max }$ of Cd(II)-PAN complex. Therefore, it is understandable that the co-existence of $\mathrm{Zn}$ (II) in the $\mathrm{Cd}(\mathrm{II})$ solution causes the absorbance of Cd(II)-PAN complex to increase.

Similarly, Fe(III)-PAN complex in chloroform can readily form at $\mathrm{pH} 4-8$, with $\lambda_{\max }$ at $775 \mathrm{~nm}[18,22]$. The closeness of the $\mathrm{pH}$ for the $\mathrm{Fe}$ (III) complexation with that of $\mathrm{Cd}$ (II) causes the competition between the two cations to form related complex with the ligand, hence the co-existence of Fe(III) in the solution contributes to the increase in the absorbance of the solution containing Cd(II)-PAN.

The co-addition of $\mathrm{Cu}(\mathrm{II}), \mathrm{Zn}(\mathrm{II}), \mathrm{Ni}(\mathrm{II})$, and $\mathrm{Fe}(\mathrm{III})$ altogether in the $\mathrm{Cd}(\mathrm{II})$ solution shows a large positive increase in absorbance of about $37 \%$, which is much higher than the sum of individual effect. This may be explained from the point of view that the formation of $\mathrm{Zn}$ (II)-PAN, Ni(II)-PAN and Fe(III)-PAN is more dominant/favourable compared to the formation of $\mathrm{Cu}$ (II)-PAN when they are present altogether, as a result, the negative effect of $\mathrm{Cu}$ (II) vanishes and only positive effect is observed when the four cations exist together in the $\mathrm{Cd}(\mathrm{II})$ solutions.

\section{Analytical application of real samples}

The developed membrane has been applied to the analysis of Cd(II) in the river water of "Kali Code". Since most of the samples do not contain Cd(II) ion, for this purpose we have used internal addition standard method and the results are displayed in Table 2. From the table, it is clearly shown that the membrane produces a good percentage of recovery in the range of $100.25-107.52 \%$. It is also observable from the table that $\mathrm{Cd}(\mathrm{II})$ content in the sample taken from location 1 and 2 could not be detected and only river water taken from location 3 contains sub-ppm of $\mathrm{Cd}(\mathrm{II})$. This result can easily be understood by considering the position of sampling points. Location 3 is located in the point where the river of "Kali Code" starts leaving city of Yogyakarta, meaning that the river water taken from this sampling point has received many waste such as domestic and industrial activities available along the river side 


\section{Moersilah et al: OPTICAL CHEMICAL SENSOR OF Cd(II) IN WATER BASED ON 1-(2-PYRIDYLAZO)-2- NAPHTOL IMMOBILIZED ON POLY(METHYL METHACRYLATE) AND 2- NITROPHENYL OCTYL ETHER MATRIX}

across the city of Yogyakarta. Some of the waste may contain heavy metals including Cd(II), therefore we detected $\mathrm{Cd}(\mathrm{II})$ in this sample. On the other hand, sampling points of location 1 and 2 are in the remote area, which is far away from domestic and industrial activities, therefore it is relatively still free from any pollutants, and this is becoming the reason that we could not detect the presence of $\mathrm{Cd}(\mathrm{II})$ ion in these two samples.

Table 2. Results of the Cd(II) analysis in the river water samples

\begin{tabular}{llcccc}
\hline No. & $\begin{array}{l}\text { River Water } \\
\text { Sample }\end{array}$ & $\begin{array}{c}\text { Cd(II) in Water } \\
\text { Sample }(\mathbf{p p m})\end{array}$ & $\begin{array}{c}\text { Added } \\
\text { Cd(II) }(\mathbf{p p m})\end{array}$ & $\begin{array}{c}\text { Cd(II) } \\
\text { Found }(\mathbf{p p m})\end{array}$ & $\begin{array}{c}\text { Recovery } \\
(\boldsymbol{\%})\end{array}$ \\
\hline 1. & Location 1 & Not detected & 1 & $1.075 \pm 0.041$ & 107.52 \\
2. & Location 2 & Not detected & 1 & $1.068 \pm 0.008$ & 106.78 \\
3. & Location 3 & 0.046 & 1 & $1.002 \pm 0.005$ & 100.25 \\
\hline
\end{tabular}

Notes: "Kali Code" is the name of river that flows across the City of Yogyakarta, Indonesia, starting from Merapi Mountain in the north to the Indian Ocean in the south. Location 1: $15 \mathrm{~km}$ from Merapi Mountain (before entering Yogyakarta City). Location 2: $13.5 \mathrm{~km}$ from location 1 (start entering Yogyakarta City). Location 3: $6.7 \mathrm{~km}$ from location 2 (before leaving Yogyakarta City).

\section{Conclusion}

A chemo-optical sensing membrane for $\mathrm{Cd}$ (II) analysis has been developed by immobilization of PAN in a matrix of PMMA using NPOE as a plasticizer. The obvious change in membrane color after contact with analyte suggests the possible application of the method for qualitative detection and the linear response of absorbance along with the change in the analyte concentration provides its application in quantitative analysis. The membrane has been successfully applied to the analysis of $\mathrm{Cd}$ (II) in the natural water with satisfactory results as indicated by good percentage of recovery. The proposed optical chemical sensor membrane can be used as an alternative method for detection and determination of $\mathrm{Cd}$ (II) in ground water as well as in waste water, which offers simple, cheap, save and environmentally friendly technique. In the future, the developed sensing membrane can also be applied in periodic monitoring of $\mathrm{Cd}(\mathrm{II})$ pollution in water and may be developed for in-situ field analysis. Another possible prospective application is to develop membrane as " $\mathrm{Cd}(\mathrm{II})$ analytical kit", which can be used for quick and real time assessment of $\mathrm{Cd}(\mathrm{II})$ in the polluted area.

\section{Acknowledgement}

The first author, Moersilah, would like to acknowledge the Ministry of Education and Culture, The Republic of Indonesia for providing doctoral scholarships. The authors thank Universitas Gadjah Mada Indonesia for the research support and facilities.

\section{References}

1. Mirzaei, M. and Pili, H. B. (2015). Potentiometric determination of cadmium using coated platinum and PVC membrane sensors based on N, N'-bis (salicylaldehyde) phenylenediamine (salophen). Journal of Analytical Chemistry, 70 (6): $731-737$.

2. Manahan, S. and Manahan, S. E. (2009). Environmental Chemistry, Ninth Edition. CRC Press, London: pp. $200-239$.

3. van der Perk, M. (2006). Soil and water contamination: from molecular to catchment scale. CRC Press, London: pp. $125-137$.

4. Urek, Š. K., Frančič, N., Turel, M. and Lobnik, A. (2013). Sensing heavy metals using mesoporous-based optical chemical sensors. Journal of Nanomaterials, 8: 1 - 13.

5. da Silva, M. C. H., da Silva, L. H. M. and Paggioli, F. J. (2005). A novel micellar medium using triblock copolymer for cobalt determination. Analytical Sciences, 21 (8): 933 - 937.

6. Ensafi, A. A., and Shiraz, A. Z. (2008). The combination of solid phase extraction and flame atomic absorption spectrometry for trace analysis of cadmium. Brazilian Journal of Analytical Chemistry, 19 (1): 11-17. 
7. Manahan, S. E. (2006). Green chemistry and the ten commandments of sustainability. $2^{\text {nd }}$ edition. ChemChar Research, Inc, Columbia: pp.159-176.

8. Koel, M., and Kaljurand, M. (2006). Application of the principles of green chemistry in analytical chemistry. Pure and Applied Chemistry, 78(11): 1993 - 2002.

9. Tobiszewski, M., Mechlińska, A. and Namieśnik, J. (2010). Green analytical chemistry - theory and practice. Chemical Society Reviews, 39(8): $2869-2878$.

10. Wardencki, W. and Namiesnik, J. (2002). Some remarks on gas chromatographic challenges in the context of green analytical chemistry. Polish Journal of Environmental Studies, 11(2): 185 - 187.

11. Tharakeswar, Y., Kalyan, Y., Gangadhar, B., Kumar, K. S. and Naidu, G. R. (2012). Optical chemical sensor for screening cadmium (II) in natural waters. Journal of Sensor Technology, (2): 68 - 74.

12. Ensafi, A. A., and Isfahani, Z. N. (2011). A simple optical sensor for cadmium ions assay in water samples using spectrophotometry. Journal of Analytical Chemistry, 66(2): 151 - 157.

13. Tavallali, H. and Kazempourfard, F. (2009). Determination of cadmium ions by designing an optode based on immobilization of dithizone on a triacetylecelluose membrane in polluted soil and water samples. Journal of the Korean Chemical Society, 53(2): $144-151$.

14. Gavrilenko, N. A. and Saranchina, N. V. (2009). Analytical properties of 1-(2-pyridylazo)-2-naphthol immobilized on a polymethacrylate matrix. Journal of Analytical Chemistry, 64(3): 226 - 230.

15. Gavrilenko, N A, Saranchina, N. V. and Gavrilenko, M. A. (2015). A colorimetric sensor based on a polymethacrylate matrix with immobilized 1-(2-pyridylazo)-2-naphthol for the determination of cobalt. Journal of Analytical Chemistry, 70(12): 1475 - 1479.

16. Ensafi, A. A and Fouladgar, M. (2014). A new sensitive optical bulk test-system for thallium based on pyridylazo resorcinol. Journal of Analytical Chemistry, 69(2): 143 - 148.

17. Ueno, K., Imamura, T. and Cheng, K. L. (1992). Handbook of Organic Analytical Reagent. $2^{\text {nd }}$ edition, CRC Press Inc, Tokyo: pp. $209-368$.

18. De, A. K., Khopkar, A. K. and Chalmers, S. M. (1970). Solvent extraction of metals. Van Nostrand Reinhold Company, London: pp. $117-124$.

19. Mohr, G. J. (2004). Polymers for optical sensors', in Baldini, F., Chester, A. N., Homola, J. and Martellucci, S. (ed.), Optical chemical sensor, Springer, The Netherland: pp. 297 - 322.

20. Hsu, S. L. (1999). Poly(methyl methacrylate), in Mark, J. E. (ed.), Polymer data handbook. Oxford University Press, Inc., Oxford: pp. $655-657$.

21. Moghimi, A. (2011). Cr(III) selective PVC membrane electrodes based on schiff base 1-(2-pyridylazo)2naphtol complex as an ionophore. Middle-East Journal of Scientific Research, 7(2): 147 -152.

22. Sandell, H. and Onishi, E. B. (1978). Photometric determination of traces of metals general aspects $4^{\text {th }}$ edition, John Wiley and Sons, Inc., New York: pp. $449-487$.

23. Moersilah, M., Siswanta, D., Roto, R. and Mudasir, M. (2017). PAN-immobilized PVC-NPOE membrane for environmentally friendly sensing of Cd(II) ions. Indonesian Journal of Chemistry, 17(1): $1-6$.

24. Donagh, C. Mc., Burke, C. S. and MacCraith, B. D. (2008). Optical chemical sensors, Chemical Reviews, 108(2): $400-422$.

25. Sombatsri, S., Wittayakun, J., Sanai, K. and Kajsanthia, K. (2012). An optical sensing film for the determination of $\mathrm{Co}(\mathrm{II})$ based on disodium-1-nitroso-2-naphthol-3,6-disulfonate immobilized in chitosan film. Sensor and Actuator B: Chemical, 166 - 167: 772 - 776. 